\title{
Imatinib for Pulmonary Arterial Hypertension - Wonder Drug or Killer Drug?
}

\author{
Horst Olschewski \\ Medical University of Graz, Graz, Austria
}

Imatinib became the first highly effective therapy for chronic myeloic leukemia (CML) by targeting BCR-ABL, a tyrosine kinase that establishes an autocrine loop in leucocytes and stromal cells, making them highly proliferative and aggressive [1]. The drug is so interesting for the pulmonologist because it is also a potent inhibitor of another tyrosine kinase, the platelet-derived growth factor receptor (PDGFR). In pulmonary arterial hypertension (PAH), PDGFR is strongly upregulated in the small pulmonary arteries $[2,3]$ and causes pulmonary vascular remodeling. Since 2003, PDGF antagonists have been thought to have therapeutic potential for PAH [4].

In 2005, in the monocrotaline rat model of pulmonary hypertension, imatinib showed excellent effects on pulmonary pressure and pulmonary vascular remodeling. It was in fact the first substance to cause impressive 'reverse remodeling' of the small pulmonary arteries in fully established pulmonary hypertension [5]. In a PAH patient who had progressed to right heart failure despite triple therapy for $\mathrm{PAH}$, i.e. an endothelin receptor antagonist, a phosphodiesterase 5 inhibitor and a prostanoid, add-on therapy with imatinib led to a remarkable improvement, from WHO FC IV to II, from 260 to $383 \mathrm{~m}$ in the 6-min walk, and from 1,538 to $815 \mathrm{dyn} \cdot \mathrm{s} \cdot \mathrm{cm}^{-5}$ in pulmonary vascular resistance [6]. In 2010, a phase II study with ima- tinib showed significant improvement in hemodynamics and physical capacity after 24 months of therapy [7].

Based on these data and independent of any interests on the part of the pharmaceutical industry, pulmonary hypertension specialists in several countries have offered open-label imatinib to their PAH patients as a palliative treatment, but, unfortunately, with little in the way of published results so far.

In Zurich, Switzerland, imatinib was offered in the framework of an observational study in which patients were treated according to an approved protocol with written informed consent and case report forms as documentation. Speich et al. [8] report this truly investigatorinitiated trial in this issue of Respiration, describing 15 $\mathrm{PAH}$ patients who received imatinib as an add-on to their conventional PAH therapy. Ten of these patients had been on triple therapy, 3 on dual, and 2 on monotherapy. The investigators performed a complete work-up at baseline, and after 6 months of therapy, and documented significant improvements in quality of life, functional class and pulmonary hemodynamics as assessed by right heart catheter studies.

In parallel, IMPRES, a phase III study on imatinib, reached its primary endpoint $(\mathrm{p}=0.002)$ and demonstrated a significant improvement in pulmonary hemo-
Prof. Dr. Horst Olschewsk Medical University of Graz Auenbruggerplatz 15 AT-8036 Graz (Austria)

E-Mail horst.olschewski@medunigraz.at 
dynamics and physical capacity [9]. The participants in the phase II and III studies were invited to take part in an imatinib extension trial, in which 144 patients received open-label imatinib treatment.

In 2012, some IMPRES data were published as an ERS abstract, showing the unexpected finding of 6 patients with subdural hematoma (SDH) out of these 144 longterm patients (4.2\%). In the previous controlled trial, another $2 \mathrm{SDH}$ had been documented in the imatinib group versus none in the placebo group. Six of these 8 patients recovered without neurological deficits, 3 of whom required craniotomy; 1 patient died of SDH and 1 of unrelated causes [9]. The sponsor of the trials withdrew the approval application.

In Zurich, the 15 patients in Speich's study were still receiving imatinib and were monitored regularly. The drug was generally well tolerated, and 3 of the patients (20\%) presented with completely normal echocardiography and brain natriuretic peptide values after about 3 years on imatinib, suggesting a 'hemodynamic remission'. One of these patients received right heart catheterization [10]; however, there were 2 other patients with
$\mathrm{SDH}$ in the course of 3 years, which is in agreement with the experience from the IMPRES trial. The investigators informed all patients of the risk of SDH and changed the target international normalized ratio from 2.5 to 2.0. From then on, there were no further bleeding events in a total of 50 patient-years.

A joint German/Austrian/Swiss expert opinion concludes that imatinib therapy may be indicated in PAH patients who are not sufficiently stabilized with approved PAH medications [11]. Considering the strong rationale based on the pathologic mechanisms of $\mathrm{PAH}$, the significant effects of the phase II and III trials, and a possible $20 \%$ chance for a 'hemodynamic remission', it may be difficult to withhold this therapy option from desperate $\mathrm{PAH}$ patients whose only remaining options are transplantation or death.

\section{Acknowledgement}

I would like to acknowledge the linguistic revision by Eugenia Lamont, Medical University of Graz.

\section{References}

1 Druker BJ: Translation of the Philadelphia chromosome into therapy for CML. Blood 2008;112:4808-4817.

- 2 Humbert M, Monti G, Fartoukh M, Magnan A, Brenot F, Rain B, Capron F, Galanaud P, Duroux P, Simonneau G, Emilie D: Plateletderived growth factor expression in primary pulmonary hypertension: comparison of HIV seropositive and HIV seronegative patients. Eur Respir J 1998;11:554-559.

- 3 Perros F, Montani D, Dorfmuller P, DurandGasselin I, Tcherakian C, Le PJ, Mazmanian M, Fadel E, Mussot S, Mercier O, Herve P, Emilie D, Eddahibi S, Simonneau G, Souza R, Humbert M: Platelet-derived growth factor expression and function in idiopathic pulmonary arterial hypertension. Am J Respir Crit Care Med 2008;178:81-88.

4 Balasubramaniam V, le Cras TD, Ivy DD, Grover TR, Kinsella JP, Abman SH: Role of platelet-derived growth factor in vascular remodeling during pulmonary hypertension in the ovine fetus. Am J Physiol Lung Cell Mol Physiol 2003;284:L826-L833.
5 Schermuly RT, Dony E, Ghofrani HA, Pullamsetti S, Savai R, Roth M, Sydykov A, Lai YJ, Weissmann N, Seeger W, Grimminger F: Reversal of experimental pulmonary hypertension by PDGF inhibition. J Clin Invest 2005; 115:2811-2821.

66 Ghofrani HA, Seeger W, Grimminger F: Imatinib for the treatment of pulmonary arterial hypertension. N Engl J Med 2005;353:14121413.

7 Ghofrani HA, Morrell NW, Hoeper MM, Olschewski H, Peacock AJ, Barst RJ, Shapiro S, Golpon H, Toshner M, Grimminger F, Pascoe S: Imatinib in pulmonary arterial hypertension patients with inadequate response to established therapy. Am J Respir Crit Care Med 2010;182:1171-1177.

8 Speich R, Ulrich S, Domenighetti G, Huber LC, Fischler M, Treder U, Breitenstein A: Efficacy and safety of long-term imatinib therapy for pulmonary arterial hypertension. Respiration 2015;89:515-524.
-9 Hoeper MM, Barst RJ, Bourge RC, Feldman J, Frost AE, Galie N, Gomez-Sanchez MA, Grimminger F, Grunig E, Hassoun PM, Morrell NW, Peacock AJ, Satoh T, Simonneau G, Tapson VF, Torres F, Lawrence D, Quinn DA, Ghofrani HA: Imatinib mesylate as add-on therapy for pulmonary arterial hypertension: results of the randomized IMPRES study. Circulation 2013;127:1128-1138.

10 Speich R, Treder U, Domenighetti G, Huber LC, Ulrich S: Weaning from intravenous prostanoids and normalization of hemodynamics by long-term imatinib therapy in severe idiopathic pulmonary arterial hypertension. Int J Clin Pharm 2014;36:256-260.

11 Hoeper MM, Opitz C, Olschewski H, Ulrich S, Speich R, Behr J, Halank M, Wilkens H, Klose H, Lange TJ, Grunig E, Seeger W, Ewert R, Borst MM, Welte T, Rosenkranz S, Ghofrani HA: Imatinib for pulmonary arterial hypertension (in German). Dtsch Med Wochenschr 2014;139(suppl 4):S151-S154. 